\title{
UJI POTENSI Bacillus sp. DAN Escherichia coli DALAM MENGHASILKAN INDOLE ACETIC ACID (IAA) TANPA MENGGUNAKAN TRIPTOFAN PADA MEDIA PERTUMBUHAN
}

\author{
Muhammad Asril \\ Program Studi Biologi, Institut Teknologi Sumatera
}

\begin{abstract}
:
Indole Acetic Acid (IAA) is the important phytohormone for boosting plantgrowth promotion. It is related with amino acid tryptophan as a precursor for building IAA. However some bacteria such as Bacillus sp. and Escherichia coli enable to produce IAA without L-tryptophan on culture medium via the tryptophan independent pathways. This study aims to determine the potential of indigenous Bacillus sp. and E. coli isolate in producing IAA via Trpindependent pathways (without L- tryptophan). The stage of this study consists of growing of isolate on liquid media without tryptophan and measuring the levels of IAA using Salkowsky method. Bacillus $s p$ and Escherichia coli could produce IAA with the concentration of $0,0236 \mathrm{mmol} / \mathrm{L}$ and 0,024 mmol/L, respectively. The concentration of IAA produced by these bacteria is quite low because of their ability to synthesis IAA from the independent tryptophan pathway. The independent tryptophan pathway means these bacteria could synthesize IAA without using tryptophan as a precursor on their growth medium.
\end{abstract}

Keyword: Bacillus sp., Escherichia coli, IAA, tryptophan

\section{Pendahuluan}

Hormon tanaman merupakan senyawa organik yang disintesis pada salah satu bagian tanaman kemudian ditransfer ke beberapa bagian yang lain. Hormon ini berperan dalam pertumbuhan tanaman, salah satunya auksin. Auksin atau nama lainnya IAA (Indole Acetic Acid) merupakan hormon tumbuh yang memegang peranan penting untuk memacu pertumbuhan dan perkembangan tanaman [1]. IAA disintesis dalam berbagai bagian tubuh tanaman dan pada umumnya akan berasosiasi dengan bagian-bagian tubuh tanaman yang sedang aktif dan berkembang seperti pada semua jenis meristem ujung tunas. Sumber hormon IAA yang alami tidak hanya dihasilkan oleh tumbuhan saja tetapi juga dihasilkan oleh bakteri [2]. Salah satu keuntungan menggunakan bakteri sebagai sumber IAA karena pertumbuhan mikrob sangat cepat dibandingkan dengan pertumbuhan tanaman dalam menghasilkan hormon IAA. Selain itu, produksi biomassa dari mikrob lebih efisien daripada memproduksi IAA dari biomassa tanaman. Mikroba yang mampu menghasilkan IAA dapat meningkatkan perpanjangan dan pembelahan sel, perkembangan jaringan, respon terhadap cahaya dan gravitasi sehingga permukaan akar menjadi lebih luas [3] dan akhirnya tanaman mampu menyerap nutrisi dari tanah lebih banyak. L-triptofan merupakan asam amino yang berfungsi sebagai prekursor dalam biosintesis IAA pada tanaman dan mikroba [4].

L-triptofan (L-Trp) sebagai prekursor fisiologis IAA, baik pada tanaman maupun pada mikroba. [5]. Penambahan L-triptofan pada media kultur dapat meningkatkan produksi IAA [1]. L-triptofan mengandung sumber senyawa aktif yang dapat memicu pertumbuhan mikrobiota dalam memproduksi IAA. Bakteri penghasil IAA mensintesis hormon tersebut melalui jalur tryptophan dependent pathway dengan senyawa intermediet indolepyruvic acid [6]. Beberapa jenis bakteri diketahui mampu meproduksi IAA melalui jalur ini antara lain Pseudomonas [5], Bacillus subtilis [7], Arthrobacter agilis [8], Azotobacter [9]. Karena tingginya harga triptofan komersial, diperlukan eksplorasi bakteri yang mampu mensintesis IAA tanpa menggunakan triptofan pada media kultur pertumbuhannya.

Beberapa bakteri mampu memproduksi IAA tanpa menggunakan triptofan sebagai prekursor melalui jalur triptofan independen, salah satunya kelompok bakteri Bacillus sp. [10]. Oleh karena itu, penelitian ini bertujuan untuk mengukur produksi IAA dari bakteri indigenous (Bacillus sp. dan Escherichia coli) yang 
ditumbuhkan pada media tanpa triptofan sehingga dapat diketahui potensi dari kedua jenis bakteri tersebut dalam menghasilkan IAA melalui jalur triptofan independen.

\section{Metode}

\subsection{Alat-alat Penelitian}

Alat-alat yang digunakan dalam penelitian ini adalah autoklaf OSK 6500, Ogawa Seiki, oven Memmert UN 55, inkubator goyang Memmert, UV-Vis spektrofotometer merk Evolution Thermoscientific.

\subsection{Bahan-bahan Penelitian}

Bahan-bahan yang digunakan di dalam penelitian ini adalah bakteri uji Bacillus sp. isolat lokal dan Escherichia coli ATCC 25922 yang merupakan koleksi dari IPB Culture Collection (IPBCC). Penelitian ini menggunakan media Nutrient Broth (NB) tanpa menggunakan L-tryptofan sebagai media pertumbuhan. Pengujian kadar IAA menggunakan reagen Salkowski yang terdiri dari $150 \mathrm{ml} \mathrm{H}_{2} \mathrm{SO}_{4}$ pekat, $7,5 \mathrm{ml}$ $\mathrm{FeCl}_{3} .6 \mathrm{H}_{2} \mathrm{O}(0,5 \mathrm{M})$. Bahan-bahan tersebut dilarutkan dalam $250 \mathrm{ml}$ akuades. Sedangkan standar pengukuran auksin yang digunakan pada penelitian ini yaitu indole acetic acid (IAA) sintesis.

\subsection{Peremajaan Kultur Bakteri Uji}

Isolat Bacillus sp. dan Escherichia coli diremajakan pada media Nutrient Broth (NB) tanpa L-triptofan didalam Erlenmeyer $250 \mathrm{ml}$, kemudian diinkubasi pada inkubator goyang pada suhu $37^{\circ} \mathrm{C}$ selama 48 jam. Isolate dilakukan dengan 3 kali pengulangan.

\subsection{Pembuatan Kurva Standar IAA}

Pembuatan kurva standar IAA menggunakan konsentrasi bertingkat dari larutan stok IAA $(0,1 \mathrm{mg} / \mathrm{ml}$ atau $100 \mathrm{ppm}$ ). Larutan stok tersebut dibuat variasi konsentrasi standar IAA dari konsentrasi $0 \mathrm{ppm}$ hingga 50 ppm (Tabel 1).

\begin{tabular}{ccc}
\hline Konsentrasi IAA $(\mathbf{p p m})$ & Akuades $(\mathbf{m l})$ & IAA stock $(\mathbf{m l})$ \\
\hline 0 & 1 & 0 \\
10 & 0,9 & 0,1 \\
20 & 0,8 & 0,2 \\
30 & 0,7 & 0,3 \\
40 & 0,6 & 0,4 \\
50 & 0,5 & 0,5 \\
\hline
\end{tabular}

Tabel 1. Variasi Konsentrasi IAA

\subsection{Pengukuran Kadar IAA}

Pengukuran kadar IAA Kultur masing-masing bakteri diambil 1,5 ml lalu disentrifugasi pada 10000 rpm selama 15 menit. Supernatan tersebut diambil dan dijadikan sebagai sampel untuk pengukuran kadar IAA. Analisis kadar IAA dapat dilakukan dengan menggunakan spektrofotometer dengan panjang gelombang $520 \mathrm{~nm}$. Masing-masing larutan standar IAA, blanko (hanya berisi akuades) serta sampel supernatan bakteri diambil sebanyak $1 \mathrm{ml}$, kemudian ditambah dengan $4 \mathrm{ml}$ reagen Salkowski. Masing-masing larutan dihomogenkan dengan menggunakan vortex secara perlahan sampai homogen, kemudian diinkubasi selama 20 menit di ruang gelap. Kemudian masing-masing larutan diukur absorbansinya menggunakan spektrofotometer pada panjang gelombang $(\lambda) 520 \mathrm{~nm}$. Hasil pengukuran absorbansi pada larutan standar IAA dibuat kurva standarnya, lalu diperoleh regresinya. Analisis data menggunakan Ms. Excel dalam pembuatan grafik. 


\section{Hasil dan Pembahasan}

Bakteri Bacillus sp. dan E. coli yang ditumbuhkan pada media tanpa L- triptofan dalam waktu 48 jam menunjukkan produksi IAA yang tidak begitu tinggi. Kadar IAA dari Bacillus sp. sebesar 4.139 ppm / 0.0236 $\mathrm{mmol} / \mathrm{L}$ sedangkan E. coli memiliki konsentrasi IAA sebesar 4,202 ppm atau setara dengan 0,024 mmol/L (Gambar 1). Beberapa faktor dapat mempengaruhi produksi IAA oleh bakteri, salah satunya jenis isolat. Isolat Bacillus sp. sudah dikenal memiliki kemampuan memproduksi IAA. Beberapa penelitian melaporkan bahwa terdapat 4 strain Bacillus spp yang mampu menghasilkan IAA sebesar 28,10 - 66,20 ppm (28,10 $66,20 \mathrm{mg} / \mathrm{L}$ ) [11]. Sedangkan E. coli hanya menghasilkan IAA sebanyak $19 \mu \mathrm{g} / \mathrm{ml}$ [12].

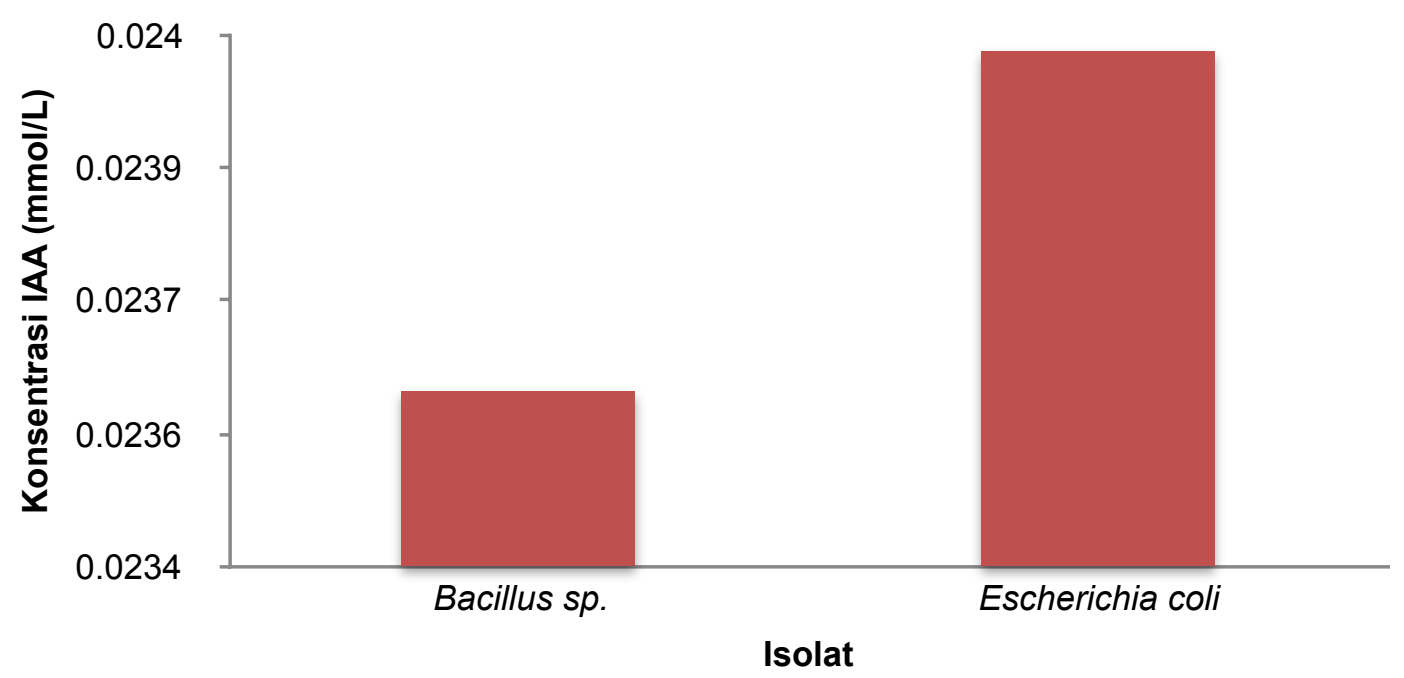

Gambar 1. Kadar konsentrasi IAA pada masing-masing isolat.

Selain jenis isolat, kadar IAA juga dipengaruhi oleh keberadaan triptofan didalam media. Triptofan merupakan prekursor dalam pembentukan IAA. Triptofan digunakan oleh mikroba sebagai sumber nitrogen untuk memproduksi IAA. Secara alami triptofan di alam diperoleh dari eksudat akar [13] dan sel mikroba [2], sedangkan secara buatan triptofan ditambahkan didalam media produksi IAA. Sebagian besar bakteri tergantung dengan keberadaan triptofan baik yang diperoleh dari eksudat akar maupun pada media pertumbuhan atau sering disebut dengan IAA triptofan dependent salah satunya Bacillus amyloliquefaciens FZB42 [14]. Pada penelitian ini, media yang digunakan untuk pertumbuhan bakteri uji tidak mengandung triptofan, akan tetapi kedua jenis bakteri ini mampu menghasilkan IAA walaupun dalam jumlah sedikit. Kedua jenis bakteri ini mampu mensintesis IAA tanpa menggunakan L-tryptofan sebagai prekursornya. Bakteri yang mampu mengahsilkan IAA tanpa L-tryptofan pada medium pertumbuhannya melalui jalur triptofan independen yaitu jalur sintesis IAA tanpa menggunakan triptofan sebagai prekursor.

Secara garis besar terdapat tiga mekanisme pembentukan IAA yaitu (1) triptofan diubah menjadi asam indolpiruvat melalui reaksi transmisi, (2) asam indolpiruvat kemudian diubah menjadi indolasetaldehida melalui reaksi dekarboksilasi, dan (3) tahap akhir adalah oksidasi indolasetaldehida menghasilkan asam indolasetat (IAA). Triptofan mengalami dekarboksilasi menjadi triptamin, kemudian triptamin dioksidasi dan dideaminisasi untuk menghasilkan indolasetaldehida. Molekul tersebut akan mengalami oksidasi lebih lanjut untuk menghasilkan asam indolasetat. Sedangkan jalur pembentukan IAA apabila tanpa adanya triptofan maka akan melalui jalur triptofan-independent. Jalur ini bercabang dari indol-3-gliserolfosfat atau indol, meskipun demikian belum ada enzim yang telah dikarakterisasi pada jalur ini (Gambar 1) [2].

Penggunaan jalur triptofan independen telah banyak dilakukan oleh bakteri salah satunya Bacillus sp. Dua isolat Bacillus yaitu Paenibacillus sp. dan Bacillus sp. mampu menghasilkan IAA pada media yang tidak mengandung triptofan yaitu sebesar $1,4-1,9 \mu \mathrm{g} / \mathrm{ml}$ [10]. Sintesis IAA melalui jalur ini dilakukan oleh bakteri baik oleh Bacillus sp. maupun $E$. coli dengan cara menggunakan asam amino aromatik lain sebagai substrat untuk menghasilkan IAA [15]. Asam amino aromatik yang digunakan yaitu fenilalanin, tirosin bahkan aspartat. Asam amino ini digunakan sebagai satu-satunya sumber nitrogen oleh bakteri untuk memproduksi IAA. Keberadaan asam amino ini hanya mampu memproduksi IAA dalam jumlah sedikit seperti yang ditunjukkan oleh Pantoea agglomerans [16]. 


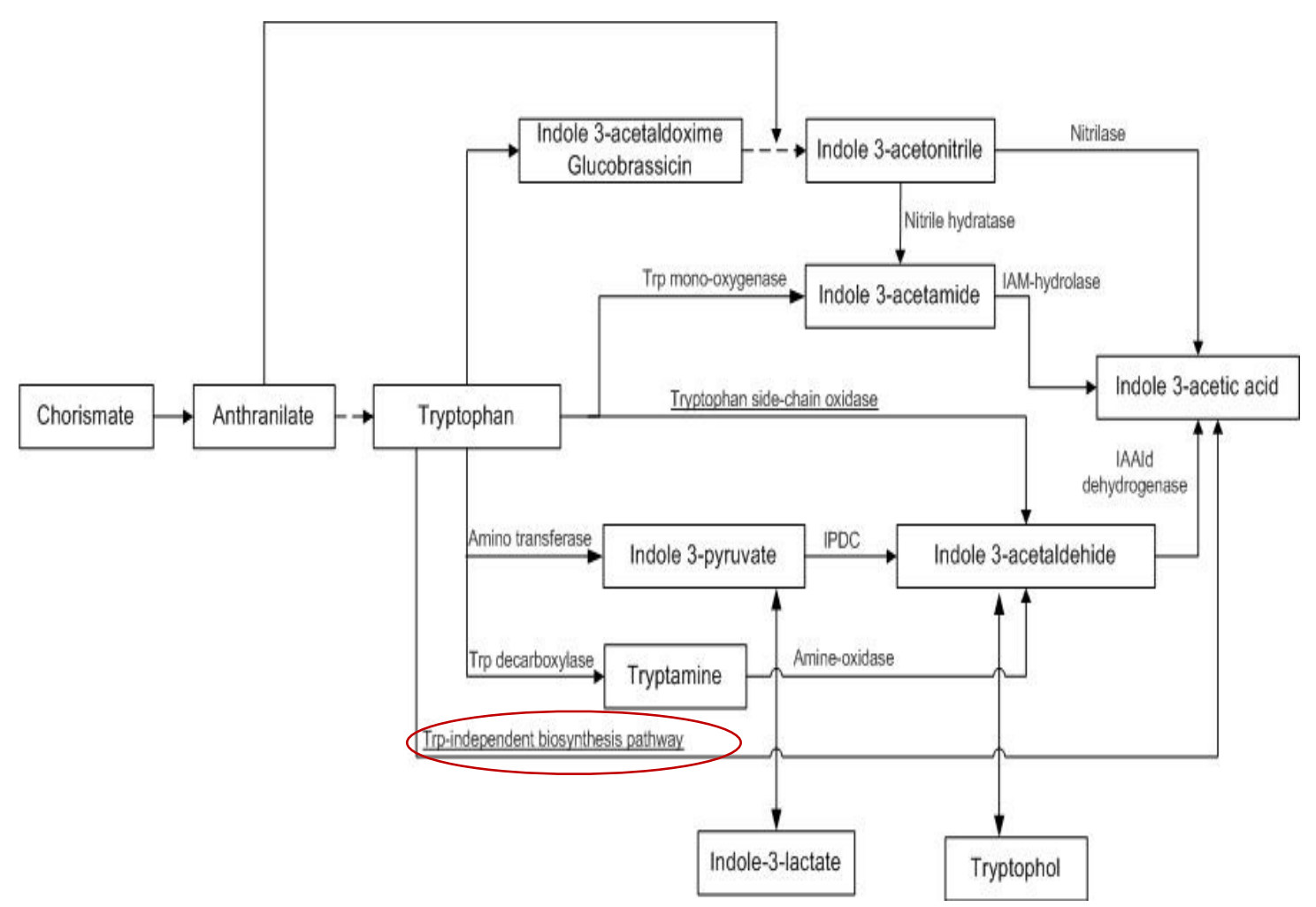

Gambar 2 Jalur biosintesis IAA [2].

\section{Kesimpulan}

Kedua jenis isolat bakteri mampu menghasilkan Indole Acetic Acid (IAA) tanpa menggunakan Ltrytofan sebagai prekursor pada media pertumbuhannya. Escherichia coli mensintesis IAA sebesar 0,024 $\mathrm{mmol} / \mathrm{L}$ lebih tinggi daripada Bacillus sp. yang memiliki konsentrasi IAA sebesar 0,0236 $\mathrm{mmol} / \mathrm{L}$. Hal ini menunjukkan bahwa Kedua jenis bakteri ini memiliki potensi sebagai penghasil IAA tanpa menggunakan prekursor L-triptofan.

\section{Daftar Pustaka}

[1] T.K. Dewi, J. Suryanggono, D, Agustiyani, " Isolasi dan ujiaktivitas bakteri penghasil hormone tumbuh IAA (indole-3-acetic acid) dan bakteri perombak protein dari tanah pertanian Tual, Maluku Tenggara" Pros Sem Nas Masy Biodiv Indon, vol 2, No.2, pp. 271-276, 2016

[2] S. Spaepen, J. Vanderleyden, Y. Okon, "Plant growth-promoting acions of rhizobacteria", Adv Botl Res, vol. 51, pp. 283-320, 2009

[3] R. S. D. P. Raj, G. R. Rex. " Modified medium for isolation and preliminary screening of indole acetic acid (IAA) producing bacteria from soil samples". Int. J.Modn. Res. Revs, vol. 2, no. 9, pp. 275-276, 2014

[4] N.B. Patil, M. Gajbhiye, S.S. Ahiwale, A.B. Gunjal, B.P. Kapadnis. "Optimization of Indole 3-acetic acid (IAA) production by Acetobacter diazotrophicus L1 isolated from sugarcane.Intl J Environment Sci, vol.2, no. 1, pp. 307-314, 2011

[5] S. Tabatabei, P. Ehsanzadeh, H. Etesami, H. A. Alikhani, B.R. Glick, "Indole-3-acetic acid (IAA) producing Pseudomonas isolates inhibit seed germination and a-amylaseactivity in durum wheat (Triticum turgidum L.)". Spanish Journal of Agricultural Research, vol 14, no. 1, pp.1-10, 2016

[6] B. Mohite, "Isolation and characterization of indole acetic acid (IAA) producing bacteria from rhizospheric soil and its effect on plant growth". J. Soil Sci Plant Nutr. Vol. 13, no. 3, pp. 638-649, 2013

[7] S. Reetha, G. Bhuvaneswari, P. Thamizhiniyin, T.R. Mycin, "Isolation of indole acetic acid (IAA) producing rhizobacteria of Pseudomonas fluorescens and Bacillus subtilis and enhance growth of onion (Allium cepa L)", Intl J Curr Mlcrobiol and Apl Sci, vol. 3, no. 2, pp.568-574, 2014

[8] M. Ozdal, O. G. Ozdal, A. Sezen, O. F. Algur and E. B. Kurbanoglu, "Continuous production of indole-3-acetic acid by immobilized cells of Arthrobacter agilis," 3 Biotech, vol. 7, pp.1-6, April 2017 
[9] M. M. Sahasrabudhe, "Screening of rhizobia for indole acetic acid production," Ann Biological Research, vol. 2, pp. 460-468, 2011

[10] J. J. Acuna, M. A. Jorquera, O. A. Martinez, D. Menezes-Blackburn, P. Greiner and M. L. Mora, "Indole acetic acid and phytase activity produced by rhizosphere bacilli as effected by $\mathrm{pH}$ and metals," J Soil Sci Plant Nutrition, vol. 11, pp.1-12, 2011.

[11] K. M. Lwin, M. M. Myint, T. Tar and W. Z. M. Aung, "Isolation of plant hormone (indole-3-acetic acidIAA) producing rhizobacteria and study on their effects on maize seedling," Engineering Journal, vol. 16, pp.137-144, 2012

[12] B. Ali, A. Sabri, K. Ljung, and S. Hasnain, "Quantification of indole-3-acetic acid from plant associated Bacillus spp. And their phytostimulatory effect on vigna radiata L.,"World J Microbiol Biotechnol, vol. 25, pp.519-526, 2009

[13] F. Ahmad, I. Ahmad and M. S. Khan, "Indole acetic acid production by the indigenous isolated of Azotobacter and fluorescent Pseudomonas in the presence and absence of tryptophan," Turk J Biol, vol. 29, pp.29-34, 2005.

[14] E.E. Idris, D.J. Iglesias, M.Talon and R. Borris, "Trytophan-dependent production of indole-3-acetic acid (IAA) affects level of plant growth promotion by Bacillus amyloliquefaciens FZB42," Mol Plant Microbe Interact, vol. 20, pp. 619-626, June 2007

[15] A. G. Moat, J. W. Foster, and M. P. Spector. Microbial Physiology. New York (US): Wiley-Liss, 2002

[16] E. Sergeeva, D. Hirkala, and L. Nelson, "Production of indole-3-acetic acid, aromatic amino acid aminotransferase activities and plant growth promotion by Pantoea agglomerans rhizosphere isolates," Plant and Soil, vol. 297, pp.1-13, 2007. 